6. Хубов Г. Мусоргский. М.: Музыка, 1969. 803 с.

7. Чистякова И. О жанрах российской словесности. URL: http://asu.edu. ru/images/File/Publikatzii/O_Zhanrakh.pdf

\title{
REFERENCES
}

1. Vasina-Grossman, (1956). V. Russian classic romance XIX century. M.: Publishing House of the Academy of Sciences of the USSR [in Russian].

2. Likhachev, D. (1981). Poetics of ancient Russian literature. M.: Nauka, 1979. [in Russian].

3. Mussorgsky, M. (1981). Letters. M.: Music [in Russian].

4. Ogolevets, A. (1960). Word and music in vocal and dramatic genres. M.: Muzgiz [in Russian].

5. Fried, E. (1981). M. P. Mussorgsky. Problems of creativity: Research. L.: Music [in Russian].

6. Hubov, G. (1969). Mussorgsky. M.: Music [in Russian].

7. Chistyakova I. On the genres of Russian literature. URL: http://asu.edu.ru/ images/File/Publikatzii/O_Zhanrakh.pdf. [in Russian].

Стаття надійщла до редакції 13.12.2017

УДК 78.03/03.1+786.2

DOI $10.31723 / 2524-0447-2018-26-74-86$

Хе Веньлі

https://orcid.org/0000-0002-4315-3379

здобувач кафедри історії музики

та музичної етнографії

ОНМА ім. А. В. Нежданової

OdHeWenli@gmail.com

\section{МЕЛОДИЧНІ ЗАСАДИ ФОРТЕПІАННОГО СТИЛЮ Ф. ШОПЕНА: АКТУАЛЬНІ МУЗИКОЗНАВЧІ ПІДХОДИ}

Метою статті є інтегративне представлення музикознавчих підходів до мелодійної парадигми фортепіанної творчості Ф. Шопена як до стильової, відтак когнітивно-мовної. Методологія роботи утворюється перетином історіографічного та жанрово-стильового методів вивчення фортепіанної спадщини композиторів-романтиків. Наукова новизна дослідження зумовлена підходом до мелодичності музичного тексту та мелодійного змісту фортепіанних творів Шопена як явищ стильового походження, пов'язаних не лише з природою інструмента, а й з музично-образним мисленням композитора та притаманними йому засобами музичного мовлення. Висновки статті засвідчують, що в творчості 
Шопена формується полімелодичний метод фортепіанного письма, який відповідає поліжанровій основі його творчості та втілюється в полістилістичному контенті всіх його творів. Водночас виникають специфічно шопенівські мелодичні комплекси - парадигматичні мелодійні ознаки, що набувають функцій авторських семантичних показників.

Ключові слова: мелодичність, мелодійні ознаки, авторська семанти$\kappa a$, полімелодичний метод, фортепіанна полістилістика.

He Venley, applicant of the Department of Music History and musical ethnography Odessa National A. V. Nezhdanova Academy of Music

Melodic bases of piano style of F. Chopin: actual musicological approaches

The purpose of the article is the integrative representation of musicological approaches to the melodic paradigm of piano creativity F. Chopin as a stylistic, and thus cognitive-linguistic. The methodology of work is formed by crossing the historiographical and genre-style methods of studying the piano heritage of romantic composers. The scientific novelty of the study is determined by the approach to the melodiousness of the musical text and the melodic content of the piano works of Chopin as phenomena of stylistic nature, connected not only with the nature of the instrument, but also with the musical form of the composer's thinking and his inherent means of musical broadcasting. The conclusions of the article show that in the work of Chopin formed a polymelodic method of piano writing, which corresponds to a polygeonal basis of his work and embodied in the polystylistic content of all his works. At the same time there are specific-chopin melodic complexes - paradigmatic melodic signs, acquiring functions of author's semantic indicators.

Keywords: melodicity, melodic signs, author semantics, polymelodic method, piano polystylistics.

Хе Веньли, соискатель кафедры истории музыки и музыкальной этнографии ОНМА им. А. В. Неждановой

Мелодические основы фортепианного стиля Ф. Шопена: актуальные музыковедиеских подходы

Целью статьи является интегративное представление музыковедческих подходов к мелодической парадигме фортепианного творчества Шопена как к стилевой, поэтому когнитивно-языковой. Методология работы образуется пересечением историографического и жанрово-стилевого методов изучения фортепианного наследия композиторов-романтиков. Научная новизна исследования обусловлена подходом к мелодичности музыкального текста и мелодическому содержанию фортепианных произведений Шопена как к явлениям стилевого происхождения, связанным не только с природой инструмента, но и с музыкально-образным мышлением композитора и присущими ему средствами музыкальной речи. Выводы статьи обнаруживают, что в творчестве Шопена формируется полимелодический метод фортепианного письма, отвечающий 
полижанровой основе его творчества и воплощающийся в полистилистическом контенте всех его произведений. В то же время возникают специфически шопеновские мелодические комплексы - парадигматические мелодические признаки, приобретающие функиии авторских семантических показателей.

Ключевые слова: мелодичность, мелодические признаки, авторская семантика, полимелодический метод, фортепианная полистилистика.

Актуальність теми та проблемних питань статті зумовлюється тим, що мелодійність є специфічною авторською рисою творчості Ф. Шопена, тісно пов'язаною з вибором ним сфери фортепіанного звучання як матеріалу для музичної мови - основи музично-знакової системи.

В прихильності Шопена до фортепіано вбачається зазвичай характерна національна риса, оскільки тяжіння саме до інструментального начала є типовим для польського фольклору, який розбудовувався убік танцю та інструменталізму. Водночас польська пісенність, виразні вокальні звороти, що проникають всередину інструментальної польської музики, також зумовлюють національно-стильові риси польської музики та є спорідненими для Шопена з етнічною категоризацією музичної мови. Про єдність інструментального та вокального витоків музично-інтонаційного змісту шопенівської музики як зумовлену національно-стилістичними якостями пише більшість дослідників авторського стилю Шопена [1-8], таким чином визначаючи парадоксальне поєднання у ньому типового та оригінального, традиційно-етнічного та індивідуально-самобутнього, канонічного та інноваційного. Це спонукає до більш поглибленого вивчення жанрово-стилістичних передумов формування мелодичної мови Ф. Шопена, яка найбільше виділяє звучання його фортепіанних творів серед інших музичних артефактів доби романтизму, в той самий час, є повністю відповідною до романтичної композиторської поетики.

У працях Б. Асафьєва, К. Зенкіна, Д. Житомирського, Л. Мазеля, деяких інших $[1 ; 6 ; 7 ; 8 ; 10 ; 14 ; 15]$ справедливо зазначається, що у самій фактурі деяких шопенівських творів, наприклад, мазурок чуються відзвуки інструментальних ансамблів, що прийняті у польських селах (у Мазурці ор. 56 фортепіанна фактура відтворює звучання волинки й контрабаса; у Мазурці ор. 30 використане явне наслідування гри сільського скрипаля). Ладо-гармонічні особливості національної польської музики, що відрізнялися від академічних професійних, суттєво вплинули на музичне мислення Шопена, підказали йому низку власних художніх знахідок. 
Звертаючись до питань про мелодійний стиль Шопена, дослідники визначають і його зв'язки з мелодіями відомих оперних і пісенних (камерно-вокальних) творів, зокрема влив на нього стилістики бельканто, що сприяє прихованості контуру шопенівської мелодії в орнаментальній надлишковості фактури, коли гармонійні голоси також набувають вокальної континуальності та виразовості [3-4; 10; 11]. Тривалість, фактурна витривалість та широта, гнучкість і завершеність горизонтального розвитку, інтонаційна вагомість кожної інтонації створюють справді яскраво «співаючий» ефект та потребують спеціального вивчення й теоретичного пояснення.

Метою статті є інтегративне представлення музикознавчих підходів до мелодійної парадигми фортепіанної творчості Ф. Шопена як до стильової, відтак когнітивно-мовної.

Основний зміст роботи. Ф. Шопен формувався як музикант у багатоскладовому музичному контексті, важливою складовою якого виступала оперна творчість, зокрема твори італійських композиторів, серед яких виокремлюється стильова фаза пізнього бельканто. Відомо, що тяжіння Шопена до італійського типу оперного інтонування зумовлювалося саме мелодійними властивостями вокальної сценічної музики, що досягала особливої експресії внаслідок зв'язку зі словом та театралізованою дією. Не випадково в працях К. Зенкіна та Ю. Тюліна $[7 ; 15]$ зазначається, що для Шопена, який віддавав перевагу сталим формам музичного мислення, таким, що вже витримали перевірку часом та набули загальновизнаного смислу, тобто досягли рівня класичних, орієнтація на мелодію італійського оперного типу виявлялася найвищою мірою природньою. Завершеність та інтонаційна пластичність його мелодій зумовлена нормативною італійською кантиленою з іï узагальненими мелодраматичними показниками. Але індивідуальний зміст його мелодійних оборотів, їх вишуканий стилістичний візерунок часто пов'язані і з іншими джерелами, походження яких ховається у національних традиціях, переломлених поетикою романтизму.

Досить часто неповторно шопенівське сприймається як розспів в орнаментально-колоратурній манері певного мелодійно-тематичного контуру, створення вокально виповненої мелізматики в її суто фортепіанно-інструментальному втіленні. В «Карнавалі» Р. Шумана у відповідній «портретній» п’єсі відтворюється, як найбільш специфічна, сама ця особливість шопенівського мелодійного стилю, коли формується тип викладу, наближений до ноктюрнового. Розгорнуті 
пасажі, в яких можна розпізнати відлуння колоратурних рулад, группетто, форшлаги, звороти концертних каденцій втілені на основі тематичних побудов, «авторських слів», що мають унікальне смислове інтонаційне походження, тому запроваджують тенденцію ідіостилю - суто авторської музичної мови. Ці особистісні мовні знаки «одягнені у прийняті та відомі фактурно-розвиваючі прийоми, і це надає їм зашифрованого характеру, немов головний герой ховається у людній залі за постатями вторинних персонажів, іноді виглядаючи поверх їх голів...» [6].

Авторське походження орнаментально-мелодійного стилю Шопена варто з'ясовувати шляхом вивчення західноєвропейських професійних традицій широкого жанрового діапазону, не лише вокальних, що ведуть до італійської опери XVIII століття, а й інструментальних, що апелюють до інструментальних концертів, салонної клавірної музики. В останній дуже глибоко втілилися ознаки народного музикування, особливо в слов'янській музиці, зокрема польській, коли в п’єсах, що виконуються скрипкою або фуяркою, зустрічається тематизм типу арабески. Тут показовим прийомом - стилістичною фігурою - стає оспівування на тріольній основі, подібне до кружляння, тобто націлене на відтворення руху, як фізичного процесу і як інтенції, тобто психологічного феномена [7-8].

Подібні «тріольні лексеми» зустрічаються в музиці Шопена у значній кількості у мазурках, але також і в полонезах, вальсах, ноктюрнах, де поєднуються з мелодикою вокально-оперного складу.

I. Белза відзначає, що до національних традицій сходить така важлива риса шопенівських мелодій, як їх елегійний характер, що сприяє авторській модифікації тієї сфери інтимної лірики, що визначає авторську топосферу шопенівських творів. Меланхолійні інтонації не $є$ показовими для мелодійних «наррацій» Шопена, який часто прагне поривчастих та рішучих рухів - мелодичних жестів, різких маркатних звучань (в музиці Скерцо, Сонат, Балад), не позбавлених урочисто-героїчних та велично-епічних звучань (наприклад, As-Dur'ний полонез та f-moll'на фантазія). Музика Шопена презентувала новий авторський вимір ліричного начала тому, що відкрила нові образні можливості музики як ліричного виду мистецтва, зумовленого причетністю до вираження особистісних смислів, буття особистої свідомості. В романтичну добу ліричний стиль в музиці знаходить визнання як особистісно орієнований та психологічно поглиблений, що означає упредметнення змісту глибинної свідомості як почуттєвого. 
Тому Шопена можна вважати провідником нової сугестивної функції музики, здатної ставати «вчителем почуттів», знаряддям утворення естетичної архітектоніки особистісної свідомості.

При цьому діапазон емоційних станів - реєстр переживань, представлених в творах Шопена, є напрочуд широким, поєднуючим між собою усі динамічні прояви епічного драматико-трагічного та ліричного відношень як опорних констант художнього змісту. Художній світ Шопена, залишаючись незмінно авторським, є відкритим до усього багатства людських стосунків, почуттів та думок, до усього конгломерату образних музичних рішень, здатних транслювати імагінативну гру людської свідомості. Цьому сприяє і узагальнений вираз у творах Шопена стилістики камерно-вокальної музики, зокрема романсу монологічного складу, що характеризований синтезом пісенного та речитативного, аріозного та декламаційного, вербальної виразності та музичної закругленості інтонування.

Для Шопена досить показовими є речитативні прийоми, що вживлюються у кантиленно виповнені й завершені мелодії, причому вони зумовлені не лише оперними традиціями, а й засобами фольклорного музикування, а найбільше - авторськими розмовними зворотами, що відбивають і польський говір, і узагальнені позаетнічні мовні інтонації. Вплив різних жанрових форм - жанрових традицій в їх первинній і вторинній якості відзначається у метро-ритмічній стороні творів Шопена, що наділена суттєвою стильовою роллю. Особливу увагу привертають вільні зміни дводольних і тридольних метрів, притаманні східнослов'янській народній традиції, так само, як і контрастні зміни тематичних побудов, що відображують макроритм музичної форми та скеровані до «смислу вищого порядку» - до образної драматургії. Це особливо помітне в структурі балад, коли різке вторгнення гучних епізодів у теми ідилічного складу алюзивно звернене до польської думи, що містить чергування епічних повільних і драматично стрімких темпоритмів. Розповсюджений у Шопена прийом мелодійного варіювання також сходить до варіантного фольклорного типу розвитку, що панує в польській музиці.

Таким чином, можна сказати, що мелодичний зміст творів Шопена має енциклопедичні ознаки, узагальнює та сполучає, інтегрує усі ті мелодійні показники музичного тексту, які є найбільш показовими з боку романтичної образної експресії. Водночас стилю Ф. Шопена притаманна класична вивіреність та гармонійність, що йде від канонів класицистської естетики. 
Про специфічний класицистський нахил мислення Ф. Шопена пишуть майже всі дослідники його стилю. Сприяючи обдуманості кожної деталі, класицистська завершеність і ясність задуму сполучаються в творах Шопена з яскравістю та суто романтичною емоціональністю (психологічною рельєфністю) мелодійно-тематичного матеріалу. Увага до деталей тематично-фактурного розвитку, відпрацьованість кожної інтонації, бездоганна логіка в організації музичного матеріалу та позитивно спрямована семантика, особлива легкість світовідчуття у поєднанні з глибиною переживань та увагою до трагічних контрастів, також здатність до унікальних «психологічних контрапунктів» в образному змісті дозволяють проводити паралелі між шопенівським стильовим мисленням та «моцартіанством» в музичному мистецтві.

Б. Асафьєв невипадково помітив, що Шопен базувався не лише на останніх завоюваннях музичного західноєвропейського індивідуалізму, а й на досягненнях усталених, що визначали основний тезаурус музичного світогляду. Опора на класичні форми музичного мислення певним чином ближувала постаті Шопена та Мендельсона, творчість якого теж вирізнялася підвищеною логічністю, визначеністю композиційних рішень. Але «моцартіанство» Шопена базувалося на інших естетичних позиціях, вбираючи у себе весь набір контрастних протиставлень, що супроводжують усвідомлення непоборних протиріч буття. Зауважимо, що в мистецтві Шумана, Берліоза, Ліста, Вагнера новий емоційний лад музики не міг умістити у собі класицистські основи музичної форми, а у творчості Шопена вони органічно увійшли до оновленої романтичними ідеями архітектоніки музичної творчості, причому на багатьох ії рівнях, тобто єдність класичного та романтичного начал, як суто авторський синтез, набуває системного значення. Вона сягає і рівня виконавського піаністичного відтворення архітектонічного задуму музичного твору, тобто звучних динамічних актуалізованих способів втілення фортепіанно-текстової ідеї.

Романтична увага до деталей та контрастів співіснувала в нього з залізною логікою у побудові форми, а відкритість й безпосередність висловлення - з винахідливістю у використанні структурних принципів, інтимно-лірична сфера межувала $з$ активно-драматичною, енергія зовнішніх рухів перетікала у сили душевних поривів й навпаки. Шопен спирався на визначені принципи класицистського формотворення, якими є тричастинна репризна компози- 
ція, рондальність, сонатно-симфонічна циклічна структура, концертність та одночастинна невелика композиція, мініатюра. Щодо останньої, то Шопен є тим з композиторів-романтиків, хто суттєво сприяв перетворенню мініатюри на значущу жанрову форму, здатну виробляти власні параметри циклічності. Він заклав також принципи поемності, як похідні від збільшеної та ускладненої зсередини одночастинної п’єси. А головне те, що у кожному випадку вибору структурно-композиційного рішення композитор керувався художньою ідеєю та відповідним до неї музично-мовним матеріалом, тобто йшов від образного змісту до формальних ознак тексту [14-15].

Оригінальність шопенівських фортепіанних ідей тісно пов'язана 3 тими піаністичними установками, які він вважав головними для виявлення усього звукового тезаурусу інструмента. Серед них - ясність, інтонаційна визначеність у поданні тематичного матеріалу, тобто розуміння його стилістично-мовного походження. Шопен широко використовував прийом узагальнення через жанр, спираючись на так званий первинний стилістичний матеріал, або жанрову мову, причому впізнаваність музичних зворотів досягалась шляхом стилізації, але не цитування. Марш, народний танець, мазурка, полонез, пісня, речитатив, ноктюрн, хорал, скерцо, етюд, баркарола, балада, деякі інші, часто в складній контамінації, утворюють основу шопенівської авторської музичної мови в результаті особливого мелодичного переплавлення, яке веде до формування не лише тематичних осередків композицій, а й низки виконавських прийомів, що забезпечують фортепіанному звучанню певні образно-емоційні барви. Їх повторність, від композиції до композиції, від жанру до жанру, дозволяє передбачувати єдність фортепіанної поетики Шопена саме як виконавської в своїй основі, тобто такої, що звучить та звучанням заповнює й оформлює час. Таким чином виникає й особлива полістилістична матерія музики Шопена, у якій перетинаються поліжанрові ознаки та складні поліфонізовані мелодійні утворення - визначаються авторські музичні хронотопи [13].

Естетизація хронотопу в музиці Шопена відбувається засобами сталих розділень - розстановок музичного матеріалу, з використанням періодичності, симетрії, квадратної організації тактового розподілу, але також і з допомогою повторення-канонізації в межах авторської мови низки стилістичних зворотів, до яких входять і прийоми їх виконання. 
Тому твори Шопена відразу впізнаються, починаючи з найбільш ранніх, ще дитячих, й завершуючи опусами 40-х років. При цьому кожна жанрова форма має власні диференційні ознаки, специфічні прикмети - «стилістичне обличчя». У межах фортепіанної музики Шопен зумів позначити особливості кожного зі створених ним жанрів, надаючи їм свої неповторні стилістичні виконавські риси. Більшість з авторських шопенівських жанрових форм має власне, визначене місце в репертуарі піаністів, причому визнаючись віртуозними, відкриті ним прийоми фортепіанної гри принципово відрізняються від «гучної» віртуозності, набувають нового поглиблено-психологічного значення.

У грі самого Ф. Шопена сучасники відзначали чарівну поетичність, драматизм та, водночас, стриманість, тонкі звукові та динамічні градації, зумовлені ефектами rubato. В 1936 році французький піаніст Альфред Корто придбав у Лондоні автограф Шопена та відкрив шлях до вивчення методики виховання технічної майстерності, розробленої Шопеном. Сьогодні записи Шопена визнаються безсумнівно самобутніми та цінними у теоретичному й практичному відношеннях. Новаторство і нерозривно пов'язана з ним пізнавальна цінність технічних принципів Шопена засвідчена Ф. Лістом, що знаходить спільні з Шопеном сфери новацій фортепіанної гри [9; 16].

Принципи виховання технічної майстерності, викладені Шопеном в методичних записах, вказують на його увагу до засобів артикуляції та агогіки, оскільки з ними пов'язані інтонаційна виразність та мелодична континуальність фортепіанного звучання, ті плавність та легкість, водночас глибина, яких композитор вимагав від виконавців. Не менш важливою є орієнтація на архітектонічну точність та продуманість виконавської форми, від якої, за справедливою думкою Шопена, залежить стиль піаністичної інтерпретації [17].

Технічна система Шопена з іiї природним і зручним положенням руки, індивідуальністю пальців, різноманітністю туше, ясністю і простотою лежить в основі сучасної фортепіанної школи. Стильове спрямування технологічних вимог зумовлюється тим, що Шопен надавав музиці високе соціально-психологічне значення, вбачаючи у ній «мистецтво виражати свої думки звуками», «мистецтво управляти звуками», «прояв нашого почуття в звуках». Він вважав за необхідне насамперед відчути, визначити основну думку, поетичний характер, внутрішній стрижень виконання, наполягав на необхідності зрозуміти задум, стати на рівень творчої композиторської ідеї у виконанні 
тексту. Звідси прагнення Шопена розвивати у своїх учнів здатність міркувати, формувати й виражати образні уявлення. Шопен розглядав музику як живу рефлексивну мову людини, безмежну у своїх виразових даних саме тому, що вона є впорядкованою інтелектом. Він уподібнював музику органічній, безпосередній плинній людській мові, особливо підкреслюючи при цьому, що як одне слово не чинить мови, так один абстрактний звук не чинить музики, потрібна їх мелодійна спільність, єдність мелодично-тематичного контуру і відносно часового розгортання музики, і стосовно організації фактурно-вертикальних відношень. Звідси підсилена увага до фразування, «виконавського синтаксису», тобто взаємозв'язку і розчленованості фраз, до знаків «музичної пунктуації». За словами його учня К. Мiкулі, Шопен вважав, що той, хто не вміє правильно фразувати, не знає точно, де починається і де закінчується фраза, доводить, що музика - не його рідна мова, а щось йому чуже й незрозуміле. Звідси нелюбов Шопена до «рубаних» коротких фраз й спрямованість до фраз широкого дихання, які мають тривалу та широку мелодичну траєкторію розвитку. 3 уваги до мелодійної плавності та цілісності випливає й ставлення Шопена до ліг, фермат, штрихів та пальцевої техніки [16; 17].

У цілому прагнення та мелодійної «співучості» фортепіанної гри, навіть при іiї інструментальних жанрово-стилістичних витоках, зробили з Шопена реформатора фортепіанно-виконавського стилю. Його не могли задовольняли прийоми ізольованої пальцевої гри при фіксованому зап'ясті й кісті, тому він намагався звільнити учня від будь-якої сутості та спазматичних рухів, прищеплював еластичність, гнучкість, спирання руки не на кінчики пальців, а на «подушечки», що надає більшої «клавішно»-гучної чутливості. Культивація гри legato не заважала виробленню прийомів гри легким, мягким staccato, легким portato, далі - marcato, навпаки, сполучалась з оволодінням усіма артикуляційно-штриховими навиками.

Задля плавності руху Шопен навіть радив грати гами спершу не legato, щоб надто не затримувати перший палець при підкладанні. Співуче, зв'язане виконання, яке було кінцевою метою вправ, досягалося завдяки м'якому дотику пальців, гнучкості зап'ястя та плавності ведення руки. Шопен мав також своє особливе розуміння ідеалу «рівності пальців». Теза про використання особливих можливостей кожного пальця для досягнення звуку певної якості стала підставою новаторської аплікатури Шопена і вплинула на піаністів наступних 
поколінь вже у XX столітті (А. Шнабеля, Г. Нейгауза). Віддаючи перевагу тій чи іншій аплікатурі, Шопен керувався не стільки ії технічною зручністю, скільки ії художніми можливостями. На його думку не варто захоплюватися тим, що здається легким. Деякі аплікатурні принципи Шопена: широке використання крайніх 1 і 5 пальців на чорних клавішах; уведення незвичної послідовності пальців - 5 після 1-го або 1 після 5-го, пов'язаної зі зміною позиції руки та чергування iii розтягнутого і зібраного положення; перекладання довгих пальців через короткі; видобування декількох нот одним і тим самим пальцем. 3 усього сказаного про технічну роботу в класі Шопена стає зрозумілим, що від початку навчання він привчав учнів працювати над якістю звука, виробляти прекрасне звучання.

Вироблення краси фортепіанної гри було одним з провідних завдань композиторської та виконавської поетики Шопена. Вся творчість його була звернена до фортепіано, окрім декількох пісень та інструментальних ансамблів, а його інтерпретативний стиль базувався на глибинному розумінні органологічних та семантичних можливостей фортепіано, зумовлюючи низку жанрових та образно-мовленнєвих музичних відкриттів.

Таким чином, наукова новизна статті зумовлена підходом до мелодичності музичного тексту та мелодійного змісту фортепіанних творів Шопена як явищ стильового походження, пов'язаних не лише 3 природою інструмента, а й з музично-образним мисленням композитора та притаманними йому засобами музичного мовлення.

Висновки статті дозволяють засвідчувати, що в творчості Шопена формується полімелодичний метод фортепіанного письма, який відповідає поліжанровій основі його творчості та втілюється в полістилістичному контенті всіх його творів. Водночас виникають специфічно шопенівські мелодичні комплекси - парадигматичні мелодійні ознаки, що набувають функцій авторських семантичних показників.

\section{СПИСОК ЛІТЕРАТУРИ}

1. Асафьев Б. Шопен (1810-1849). Опыт характеристики. М., 1922.

2. Богданов-Березовский В. Шопен. Краткий очерк жизни и творчества. Л.: Тритон, 1935. 46 с.

3. Бэлза И. Фридерик Францишек Шопен / Академия наук СССР ; Институт истории искусств. М.: Издательство Академии наук СССР, 1960. 463 с.

4. Зенкин К. Фортепианная миниатюра Шопена: монография. М.: Московская консерватория, 1995. $151 \mathrm{c}$.

5. Бэлза И. Шопен. М.: Изд-во АН СССР, 1960. 462 с. 
6. Виеру Н. Драматургия баллад Шопена. О музыке: Проблемы анализа. М.: Сов.комп., 1974. С. 219-245.

7. Житомирский Д. Шопен и Шуман. Ф. Шопен. Статьи и исследования сов. музыковедов. М.: Гос. муз. изд., 1960. С. 296-322. $609 \mathrm{c}$.

8. Кремлев Ю. Фредерик Шопен: очерк жизни и творчества. М., 1971.

9. Лист Ф. Ф. Шопен. М., 1956. 158 с.

10. Мазель Л. Исследования о Шопене. М., 1971. 248 с.

11. Мильштейн М. Очерки о Шопене. М., 1987. 176 с.

12. Николаев В. Шопен-педагог. М., 1980. 93 с.

13. Самвелян Т. Полижанровость в фортепианных произведениях Шопена. М., 2000. 181 c.

14. Соловцов А. Фредерик Шопен: Жизнь и творчество. М., 1960. 465 с.

15. Тюлин Ю. О программности в произведениях Шопена. М., 1968. 66 с.

16. Фридерик Шопен: збірка статей / ред.-упорядник Я. Якубяк. Львів: Сполом, 2000. $256 \mathrm{c}$.

17. Цыпин Г. Шопен и русская пианистическая традиция. М., 1990. 96 с.

\section{REFERENCES}

1. Asafiev, B. Chopin (1810-1849). (1922). Experience characteristics. M. [in Russian].

2. Bogdanov-Berezovsky, V. (1935). Chopin. A brief sketch of life and work. L.: Triton [in Russian].

3. Belza, I. (1960). Frederic Francishek Chopin / USSR Academy of Sciences; Institute of Art History. M.: Publishing House of the Academy of Sciences of the USSR, [in Russian].

4. Zenkin, K. (1995). Chopin's Piano Miniature. Monograph. M.: Moscow Conservatory [in Russian].

5. Belza, I. Chopin. (1960). M.: Izd.-in Academ. Sciences of the USSR [in Russian].

6. Vieru, N. (1974). Dramaturgy of Chopin's Ballades // On Music: Problems of Analysis. M.: Sov.komp., P. 219-245.

7. Zhytomyr, D. (1960). Chopin and Schumann // F. Chopin. Articles and studies of owls. musicologists. M.: State. music ed., P. 296-322.

8. Kremlev, Yu. (1971). Frederic Chopin: sketch of life and work. M., Ed. 3. [in Russian].

9. List F. (1956). F. Chopin. M. [in Russian].

10. Mazel, L. (1971). Studies on Chopin. M. [in Russian].

11. Milshtein, M. (1987). Essays on Chopin. M. [in Russian].

12. Nikolaev, V. (1980). Chopin teacher. M. [in Russian].

13. Samvelyan, T. (2000). Polyphony in Chopin's piano works. M. 17.00.02 [in Russian].

14. Solovtsov, A. (1960).Frederic Chopin: Life and Work. M. [in Russian].

15. Tyulin, Yu. (1968). On programmaticity in Chopin's works. M. [in Russian]. 
16. Friederick Chopin: Collection of Articles (2000). / Editor-in-Chief Y. Yakubiak. Lviv: Spolom, [in Ukrainian].

17. Tzipin, G. (1990). Chopin and the Russian pianistic tradition. M. [in Russian].

Стаття надійщла до редакції 20.12.2017

УДК 78(477.75):008(477)](091)

DOI $10.31723 / 2524-0447-2018-26-86-98$

Тетяна Валеріївна Младенова

https://orcid.org/0000-0001-6089-6839

аспірантка Львівського національного університету імені Івана Франка, науковий співробітник музично-меморіального

музею Соломії Крушельницької

mtv_leopolis@ukr.net

\section{ДІАЛОГІЧНІ ПРОЛЕГОМЕНИ КУЛЬТУРНОГО ЛАНДШАФТУ КРИМУ (УКРАЇНСЬКИЙ КОНТЕКСТ)}

Мета дослідження - висвітити в культурному ландшафті Криму приклади діалогічної взаємодії між представниками різних культур та акцентувати уяву на українській складовій цього діалогу. Методологія дослідження. У статті використовуються спеціальні культурологічні методи дослідження: історично-ретроспективний (як метод культурної реконструкції), діахронічний, а також формально-логічні методи: аналіз і синтез, індукція й дедукція, абстрагування та ідеалізація. $\mathbf{H a -}$ укова новизна полягає в розгляді культурних, зокрема музичних, процесів, які відбуваються на півострові Крим, з позииіі вияву міжкультурних зв'язків. Висновки. Культура Криму презентована як багатоелементна, iї синкретичність зосереджена в фольклорі кримських татар як автохтонного етносу. Своїм східним вектором вона була особливо приваблива для митців-пілігримів. Кінець XIX - початок XX століття розглянуто як окремий період в історико-культурній хронології півострова. Особлива увага приділяється вивченню життєвих иляхів і творчості композитора О. Спендіарова та художника I. Айвазовського, чия біографія безпосередньо пов'язана як з Украӥною, так $і$ з Кримом, $і$ чий саме кримський період життєтворчості яскраво презентує комплементарність та плідність міжккультурного діалогу. У статті підкреслено вплив українського фольклору на композиторську діяльність О. Спендіарова.

Ключові слова: історико-культурний процес, музично-історичний процес, культурні контакти, діалог, полілог, синкретичність, національна музика.

(C) Младенова Т. В., 2018 